\title{
Molecular characterization and phylogenetic analysis of oncogenes from virulent serotype-1 Marek's disease virus in India
}

\author{
Y. PRATHIBHA, B. SREEDEVI, N. VINOD KUMAR, CH. SRILATHA
}

Department of Veterinary Microbiology, College of Veterinary Science, Sri Venkateswara Veterinary University, Tirupati - 517502, Andhra Pradesh, India

Received August 15, 2017; accepted November 28, 2017; accepted July 9, 2018

\begin{abstract}
Summary. - Marek's disease (MD) is one of the most important neoplastic diseases of poultry caused by Marek's disease virus (MDV), an oncogenic avian herpes virus, which is responsible for great economic losses to the poultry industry worldwide. Inspite of the usage of HVT and bivalent vaccines in the poultry flocks, MD continues to be a major threat to the poultry industry in India. In the present study, MD outbreaks were reported in poultry farms from different regions of Andhra Pradesh, India. The postmortem examination of dead birds showed presence of lymphomas in different visceral organs suggestive of virulent oncogenic MDVs. Histopathological examination revealed infiltration of pleomorphic lymphoblastoid cells typical of MD. The blood and tissue samples were collected and PCR was standardized targeting a $132 \mathrm{bp}$ tandem repeat region specific for serotype-1 MD viruses. Further, the characterization of the oncogenes i.e. Meq and viral interleukin 8 (vIL-8) was carried out by PCR and nucleotide sequencing. The sequence analysis of Meq gene of different clinical cases from India revealed $>99 \%$ homology with RB1B (very virulent) and GA (virulent) strains and that of vIL-8 gene showed $>99 \%$ identity with virulent strains LS and LMS. Phylogenetic analysis of oncogenes was carried out with other available sequences in the GenBank. Finally, we conclude that MDV strains obtained in the present outbreaks in India could be designated as virulent or very virulent pathotypes based on nucleotide, amino acid and phylogenetic analysis of the viruses.
\end{abstract}

Keywords: Marek's disease; virulent MDV; PCR; oncogenes; poultry; India

\section{Introduction}

Marek's disease virus (MDV) is an oncogenic avian herpes virus, which is responsible for great economic losses to the poultry industry worldwide. MDV belongs to the family Herpesviridae, the subfamily Alphaherpesvirinae, and the genus Mardivirus (Marek's disease like viruses). MDV-Herpes virus group has been divided into three serotypes based on their biological properties, by using the type specific monoclonal antibodies, as serotype-1, -2 and -3 (Bulow and Biggs, 1975). Serotype- 1 includes oncogenic MDV, serotype 2 includes non-oncogenic MDV and serotype-3 includes herpes virus

E-mail: yprathiba@gmail.com; phone: +919182322765.

Abbreviations: $\mathrm{MD}=$ Marek's disease; $\mathrm{MDV}=\mathrm{MD}$ virus; HVT = herpes virus of Turkey; Meq = Marek's Eco-RI Q; vIL-8 = viral interleukin 8 of turkey (HVT) (Witter et al., 2005). All three serotypes share common antigens.

Initially, chickens were protected efficiently by vaccination with Herpes virus of turkey and MD was well controlled by widespread use of commercially available HVT vaccines. Later on, bivalent vaccines consisting of HVT and serotype-2 herpes virus (SB-1) were introduced to control the Marek's disease in India. Of late, even after vaccination with bivalent vaccines, outbreaks of MD are being reported in chickens of 21-40 weeks age group with high mortality rates. Earlier, the clinical manifestation of MD was seen as paralytic/ classical form, but now it is more towards the oncogenic $\mathrm{MD}$ with tumor formation in different visceral organs. The increased evidence of MD in vaccinated poultry flocks could probably be attributed to the continuing evolution of more virulent MDV strains despite widespread vaccination (Biggs and Nair, 2012). There was gradual emergence of virulent 
pathotypes of MD ranging from mild (m) MDV to virulent $(\mathrm{v})$, very virulent (vv) and very virulent plus (vv+) MDV's in the field outbreaks in different countries of the world (Witter, 1997).

The molecular mechanism for MDV pathogenicity and oncogenecity remain largely unknown. Moreover, virusencoded factors (oncogenes) contributing to the enhanced virulence of MDV field strains remain uncharacterized. Several genes unique for MDVs have been identified. Among these genes, Meq and vIL- 8 were reported to have the greatest possibility to be associated with viral oncogenecity and pathogenicity. Therefore, molecular characterization and sequence analysis of these oncogenes (Meq and vIL-8) can help to decipher the molecular characteristics of field MDVs (Tian et al., 2011) and further evolutionary changes that are occurring in the virus in developing virulence can be understood. In the present study, we report the incidence of virulent serotype-1 MDV strains and their phylogenetic relationship with other MDVs from Andhra Pradesh, India.

\section{Materials and Methods}

Samples. Severe MD outbreaks were experienced in different poultry flocks of Andhra Pradesh, India, despite bivalent vaccination with HVT and SB-1 strains. A total of 27 blood samples from live suspected birds and 84 tissue samples from post mortem cases were collected from MD outbreaks of different regions. Different organs including liver, spleen, kidneys, ovaries, heart, sciatic nerve and proventriculus with visible lymphomatosis and enlargement were collected in sterile sample containers and stored at $-20^{\circ} \mathrm{C}$ until further use and part of representative organs were also stored in $10 \%$ formal saline for histopathological examination.

Histopathological examination. Representative tissue samples showing lymphomatosis were collected in $10 \%$ formal saline and processed by paraffin embedding procedure (Culling, 1974). The paraffin-embedded tissues were sectioned at $4 \mu \mathrm{m}$ thickness and stained by routine haematoxylin and eosin staining procedure. The stained sections were examined for the histological changes.

DNA extraction. Buffy coat was separated from heparinized blood samples by density gradient centrifugation using Lymphoprep (Sambrook and Russell, 2001). The extraction of DNA from buffy coat was done using QIAamp ${ }^{\oplus}$ DNA Blood Mini Kit (QIAGEN) following manufacturer's instructions.

The extraction of DNA from tissues was done using alkaline lysis method. In brief, the sliced tissue samples were treated with $400 \mu \mathrm{l}$ of tissue lysis buffer $(0.5 \mathrm{~mol} / \mathrm{l}$ Tris $\mathrm{HCl}, 0.5 \mathrm{~mol} / \mathrm{l} \mathrm{EDTA}, 2 \% \mathrm{SDS})$ and $200 \mu$ g proteinase $\mathrm{K} / \mathrm{ml}$ and incubated at $37^{\circ} \mathrm{C}$ overnight. Then an equal volume of phenol : chloroform : isoamylalcohol (25:24:1 $\mathrm{v} / \mathrm{v}$ ) was added to the lysate and centrifuged. The aqueous phase was separated and precipitation of DNA was done with double volume $100 \%$ isopropyl alcohol with $15 \mathrm{~min}$ of incubation, followed by a washing step with $70 \%$ isopropyl alcohol. Finally, the pellet was air dried and suspended in $400 \mu$ of sterile nuclease free water and stored at $-20^{\circ} \mathrm{C}$ until used.

MDV detection by PCR amplification of $132 \mathrm{bp}$ tandem repeats. As the primers of $132 \mathrm{bp}$ repeat region identifies serotype-1-specific MDVs, it was considered as diagnostic primer for the detection of MDV that can differentiate serotype-1 field MDV strains from vaccine strains. The sequences of the primers used for PCR targeting 132 bp repeat region are shown in Table 1.

PCR amplification of $132 \mathrm{bp}$ repeat region was carried out using $2 \mu \mathrm{l}$ DNA as template in a total volume of $25 \mu \mathrm{l}$ containing $2.5 \mu \mathrm{l}$ 10x Taq DNA polymerase buffer, $1.5 \mu \mathrm{l}$ of $25 \mathrm{mmol} / \mathrm{l}$ magnesium chloride, $0.5 \mu \mathrm{l}$ of $10 \mathrm{mmol} / \mathrm{l} \mathrm{dNTPs}, 1 \mu \mathrm{l}$ of Taq DNA polymerase, $1 \mu \mathrm{l}$ of $10 \mathrm{pmol} / \mathrm{l}$ of each of the two primers, and $15.5 \mu \mathrm{l}$ of nuclease free water. The optimum conditions for this amplification were as follows: Initial denaturation at $94^{\circ} \mathrm{C}$ for $4 \mathrm{~min}, 35$ cycles of denaturation at $94^{\circ} \mathrm{C}$ for $1 \mathrm{~min}$, annealing at $56^{\circ} \mathrm{C}$ for $1 \mathrm{~min}$, elongation at $72^{\circ} \mathrm{C}$ for $1 \mathrm{~min}$, final elongation at $72^{\circ} \mathrm{C}$ for $10 \mathrm{~min}$ and hold at $4^{\circ} \mathrm{C}$ for $5 \mathrm{~min}$.

PCR amplification of oncogenes. Amplification of full-length Meq and vIL-8 genes was carried out using specific primers (Table 1).

The PCR reaction mix consisted of $2.5 \mu \mathrm{DNA}$ as template in a total volume of $25 \mu \mathrm{l}$ containing $2.5 \mu \mathrm{l} 10 \mathrm{x}$ Taq DNA polymerase buffer, $1 \mu \mathrm{l}$ of $25 \mathrm{mmol} / \mathrm{l}$ magnesium chloride, $1 \mu \mathrm{l}$ of $10 \mathrm{mmol} / \mathrm{l}$ dNTPs, $1 \mu \mathrm{l}$ of Taq DNA polymerase, $1 \mu \mathrm{l}$ of $10 \mathrm{pmol} / \mathrm{l}$ of each of the two primers, and $14.5 \mu \mathrm{l}$ of nuclease free water. The optimum conditions for PCR of Meq and vIL-8 genes were as follows: Initial denaturation at $94^{\circ} \mathrm{C}$ for $4 \mathrm{~min}, 35$ cycles of denaturation at $94^{\circ} \mathrm{C}$ for $1 \mathrm{~min}$, annealing at $59.4^{\circ} \mathrm{C}$ for $1 \mathrm{~min}$, elongation at $72^{\circ} \mathrm{C}$ for $1 \mathrm{~min}$, final elongation at $72^{\circ} \mathrm{C}$ for $10 \mathrm{~min}$ and hold at $4^{\circ} \mathrm{C}$ for $5 \mathrm{~min}$. The amplified PCR products were separated on $1 \%$ agarose gels and visualized using Gel documentation (Alpha Innotech) after staining

Table 1. Primers used for PCR targeting 132 bp repeat region, Meq and vIL-8 genes

\begin{tabular}{llcc}
\hline Gene & Primer sequence & Length (nucleotides) & GC content (\%) \\
\hline MD-132- F & 5' ATG CGA TGA AAG TGC TAT GGA G 3' & 22 & 45.5 \\
MD-132- R & 5' ATC CCT ATG AGA AAG CGC TTG a 3' & 22 & 45.5 \\
Meq - F & 5' GGC ACG GTA CAG GTG TAA AGA G 3' & 22 & 54.5 \\
Meq- R & 5' GCA TAG ACG ATG TGC TGC TGA G 3' & 22 & 54.5 \\
vIL-8 - F & 5' GAG ACC CAA TAA CAG GGA AAT C 3' & 22 & 45.5 \\
vIL-8 - R & 5' TAG ACC GTA TCC CTG CTC CAT C 3' & 22 & 54.5 \\
\hline
\end{tabular}




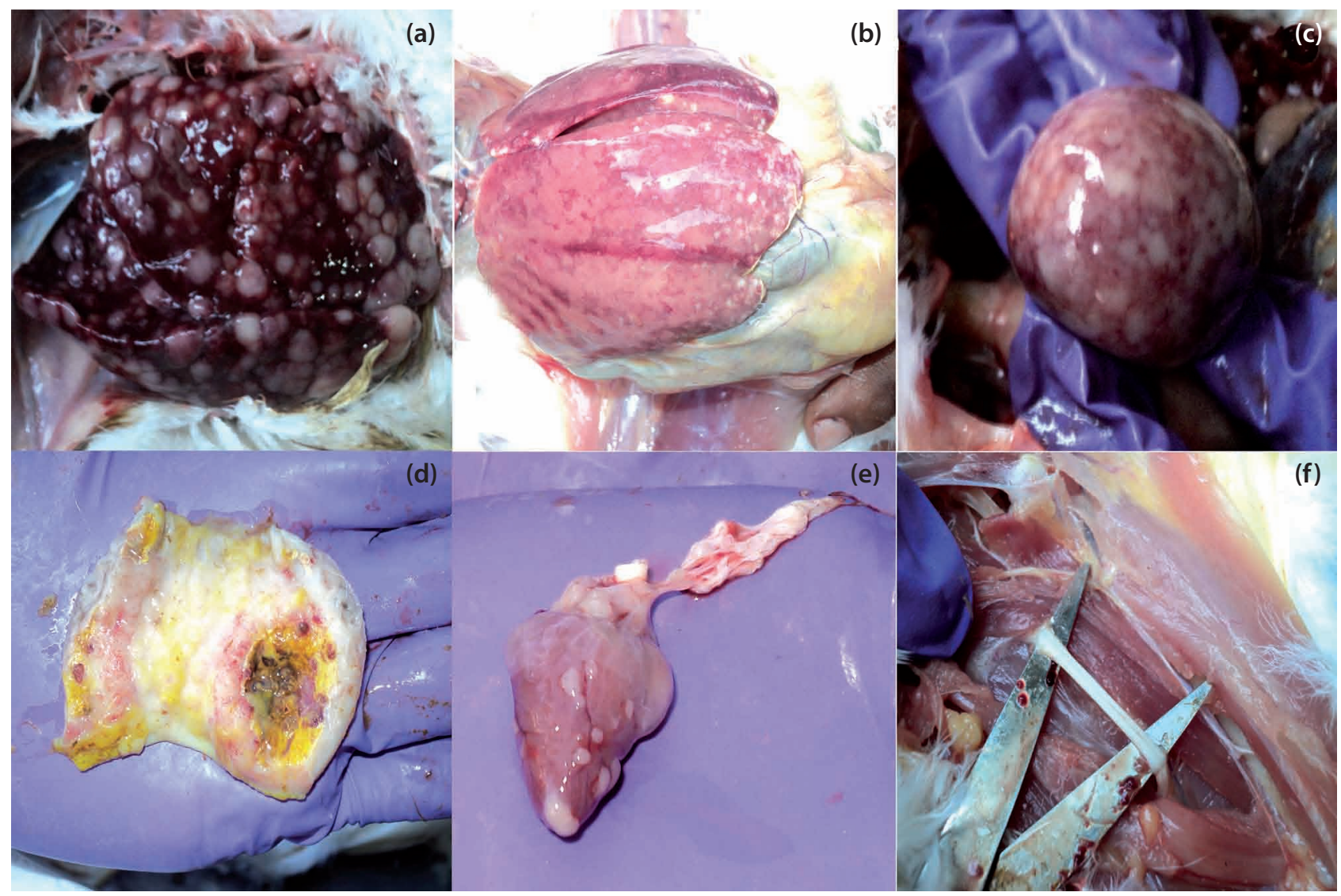

Fig. 1

Gross lesions of organs in MD affected birds

(a) Enlarged liver with multifocal whitish nodules of 4-5 $\mathrm{mm}$ in diameter; (b) Enlarged liver with multifocal grayish white nodules of pinpoint to $4 \mathrm{~mm}$ in size; (c) Spleen showing greyish white multi focal nodules; (d) Thickened proventricular wall with ulceration of proventricular mucosa; (e) Multifocal grayish white nodules of $0.5-1 \mathrm{~mm}$ in diameter over the epicardial surface of heart; (f) Sciatic nerve showing edema and loss of cross striations.

with ethidium bromide. The desired PCR products from agarose gels were purified using QIAquick ${ }^{\otimes}$ Gel extraction kit (QIAGEN) as per the manufacturer's instructions.

Sequencing of PCR products. Representative samples from different regions were selected and the purified PCR products of Meq and vIL- 8 genes were sent for sequencing at Genomics corp- Xcelris, Ahmedabad, India using gene-specific primers.

Sequence analysis of oncogenes. The obtained nucleotide sequences and the deduced amino acid sequences of Meq and vIL-8 genes of MDV were analyzed and compared with other reference sequences from GenBank database using MEGA 6.0 software.

Phylogenetic analysis of Meq and vIL-8 genes. Phylogenetic analysis was carried out using MEGA 6.0 software by Neighbor joining method using Tajima nei model with 1000 boot strap replications.

\section{Results}

\section{Clinical signs, gross lesions and histopathology}

Birds showed signs of paleness of combs and wattles, feather loss at neck region with enlargement of feather follicles. Grossly, in majority of the MD cases, the liver, spleen, proventriculus and kidneys were affected. Less commonly, sciatic nerve, ovaries, heart, mesentry and lungs were affected. All organs showed enlargement with discrete grayish white nodules of various sizes (Fig. 1). Organs like liver, spleen, kidneys, ovaries and proventriculus collected from dead birds in 10\% formal saline were subjected to histopathological examination. The results showed extensive infiltration of pleomorphic cells with lymphocytes, plasma cells and macrophages (Fig. 2). 

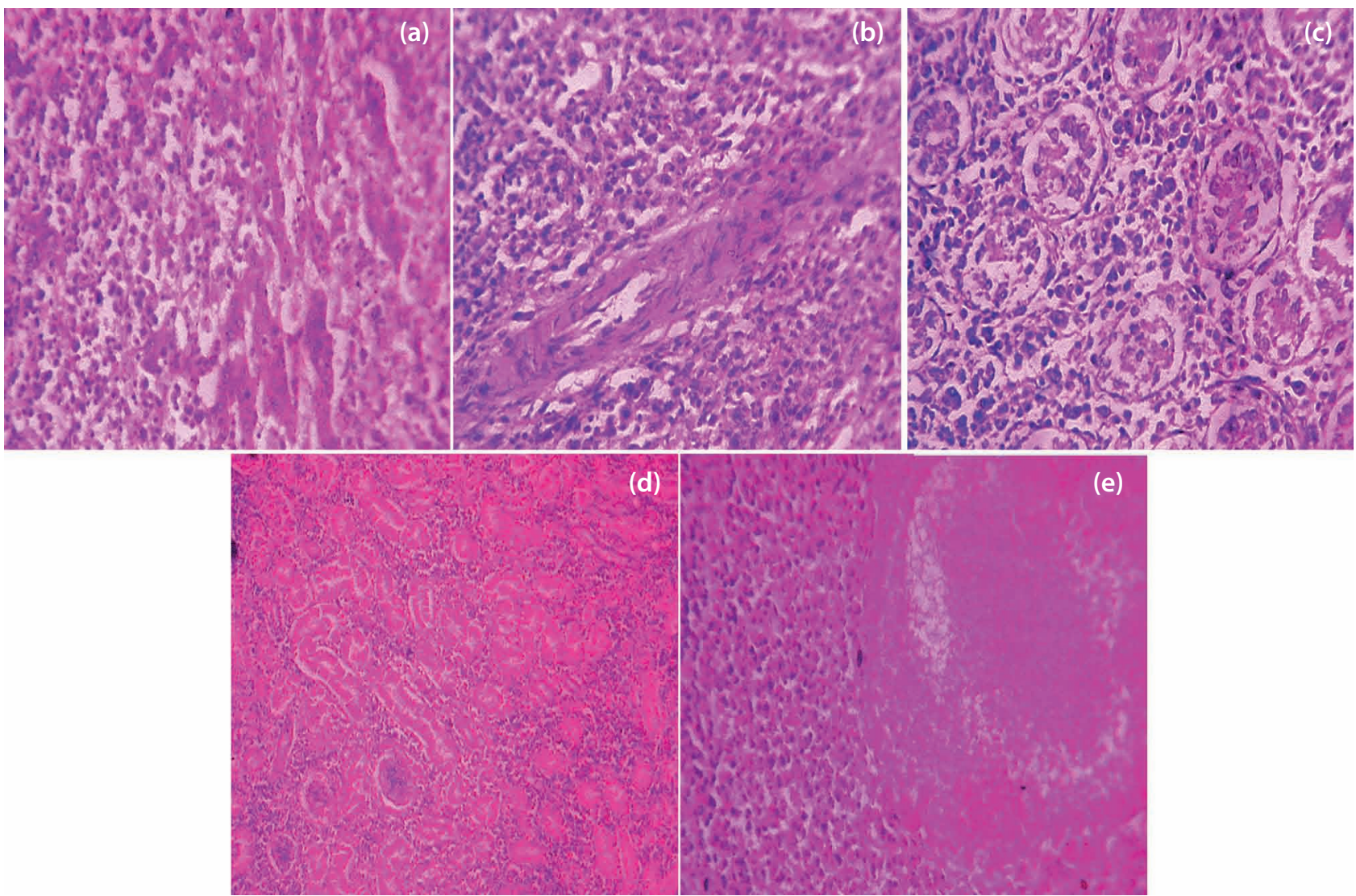

Fig. 2

Histopathological examination of tissue sections in MD affected birds

(a) Section of liver showing extensive proliferation of pleomorphic lymphoid cells in between hepatic cords resulted in loss of hepatic architecture and replacement of hepatic parenchyma, H\&E x280; (b) Spleen section showing pleomorphic lymphoid cell infiltration, H\&E x280; (c) Proventriculus showing extensive infiltration of pleomorphic lymphoblast cells in between proventricular glands, H\&E x280; (d) Kidney section showing extensive infiltration of lymphoblast cells, into interstitial connective tissue and obliteration of renal tubules, H\&E x280; (e) Ovary showing extensive pleomorphic cell infiltration leading to obliteration of ovarian parenchyma, H\&E x280.

\section{PCR targeting 132 bp repeat region}

Standardization of PCR targeting 132 bp repeat region was done using a positive MD DNA sample, which was obtained from Project Directorate on Poultry, Hyderabad, India. A 35-cycle PCR with annealing temperature of $56^{\circ} \mathrm{C}$ and $1.5 \mathrm{mmol} / \mathrm{l}$ concentration of magnesium chloride was found to be optimum for the amplification of $182 \mathrm{bp}$ product size with a single copy of 132 bp repeat region. Out of 84 tissue and 27 blood samples collected, all the tissue samples and 20 blood samples were found to be positive for serotype1 -specific MD yielding a 314 bp product in PCR amplification (Fig. 3a).

\section{PCR targeting oncogene}

The DNA samples, which were positive for $132 \mathrm{bp}$ repeat region, were further used for amplification of oncogenes.
Standardization of PCR targeting oncogenes (Meq and vIL-8) was done by keeping a 35-cycle PCR reaction with annealing temperature of $59.4^{\circ} \mathrm{C}$. The concentration of magnesium chloride at $2.0 \mathrm{mmol} / \mathrm{l}$ was found to be optimum for the amplification of $1081 \mathrm{bp}$ product of Meq gene and 887 bp product of vIL- 8 gene. All 84 tissue samples and 20 blood samples were found to be positive for the presence of viral oncogenes (Fig. 3b and 3c). The purified PCR product of four positive samples of Meq and vIL-8 genes from each region of Andhra Pradesh, India, were sent for sequencing to Genomics corp- Xcelris, Ahmedabad.

Nucleotide sequence analysis of oncogenes (Meq and vIL-8)

The obtained nucleotide sequences of Meq and vIL-8 genes from four different regions of Andhra Pradesh (Tirupati, Guntur, Chittoor, Tanuku designated as AP01, AP02, AP03 and AP04) were verified by NCBI-BLAST and sequences 
Table 2. Details of nucleotide sequences of Meq and vIL-8 genes of different field samples from Andhra Pradesh submitted to GenBank

\begin{tabular}{cccc}
\hline S. No. & $\begin{array}{c}\text { Code of the } \\
\text { sequence }\end{array}$ & Geographic origin & Acc. No. \\
\hline 1. & AP01 Meq & Tirupati & KT246100 \\
2. & AP02 Meq & Guntur & KT246101 \\
3. & AP03 Meq & Chittoor & KT246102 \\
4. & AP04 Meq & Tanuku & KT246103 \\
5. & AP01 vIL-8 & Tirupati & KT272874 \\
6. & AP02 vIL-8 & Guntur & KT272875 \\
7. & AP03 vIL-8 & Chittoor & KT272876 \\
8. & AP04 vIL-8 & Tanuku & KT272877 \\
\hline
\end{tabular}

showed homology with Meq and vIL-8 genes of different serotype-1-specific MDV strains. The accession numbers for oncogenes from different regions AP01, AP02, AP03 and AP04 were KT246100, KT246101, KT246102, KT246103 for Meq gene and KT272874, KT272875, KT272876, KT272877 for vIL-8 gene, respectively (Table 2).

Table 3. MDV reference strains of Meq gene published in GenBank

\begin{tabular}{|c|c|c|c|c|}
\hline S. No. & MDV strains & Virulence & $\begin{array}{l}\text { Geographic } \\
\text { origin }\end{array}$ & Acc. No. \\
\hline 1 & CU-2 & Mild & USA & DQ534538 \\
\hline 2 & CVI988 & $\begin{array}{l}\text { Commercial } \\
\text { vaccine }\end{array}$ & Netherland & DQ534538 \\
\hline 3 & BC-1 & Virulent & USA & AY362707 \\
\hline 4 & JM & Virulent & USA & AY243331 \\
\hline 5 & 567 & Virulent & USA & AY362709 \\
\hline 6 & 571 & Virulent & USA & AY362710 \\
\hline 7 & 573 & Virulent & USA & AY362711 \\
\hline 8 & $617 \mathrm{~A}$ & Virulent & USA & AY362712 \\
\hline 9 & GA & Virulent & USA & M89471 \\
\hline 10 & Md-5 & Very virulent & USA & AF243438 \\
\hline 11 & RB-1B & Very virulent & USA & AY243332 \\
\hline 12 & 549 & Very virulent & USA & AY362714 \\
\hline 13 & $643 \mathrm{P}$ & Very virulent & USA & AY362716 \\
\hline 14 & 595 & Very virulent & USA & AY362715 \\
\hline 15 & $\mathrm{~L}$ & Very virulent plus & USA & AY362717 \\
\hline 16 & $\mathrm{~N}$ & Very virulent plus & USA & AY362718 \\
\hline 17 & New & Very virulent plus & USA & AY362719 \\
\hline 18 & $\mathrm{~W}$ & Very virulent plus & USA & AY362723 \\
\hline 19 & $\mathrm{X}$ & Very virulent plus & USA & AY362724 \\
\hline 20 & $648 \mathrm{~A}$ & Very virulent plus & China & AF493558 \\
\hline 21 & $584 \mathrm{~A}$ & Very virulent plus & USA & DQ534532 \\
\hline 22 & Tn-n1 & Very virulent & Tamil Nadu & HM749324 \\
\hline 23 & Tn-n2 & Very virulent & Tamil Nadu & HM749325 \\
\hline 24 & Ind/KA12/02 & Isolate & Tamil Nadu & KP342383 \\
\hline 25 & Ind/TN11/01 & Isolate & Tamil Nadu & KP342384 \\
\hline 26 & Ind/TN12/03 & Isolate & Tamil Nadu & KP342385 \\
\hline
\end{tabular}
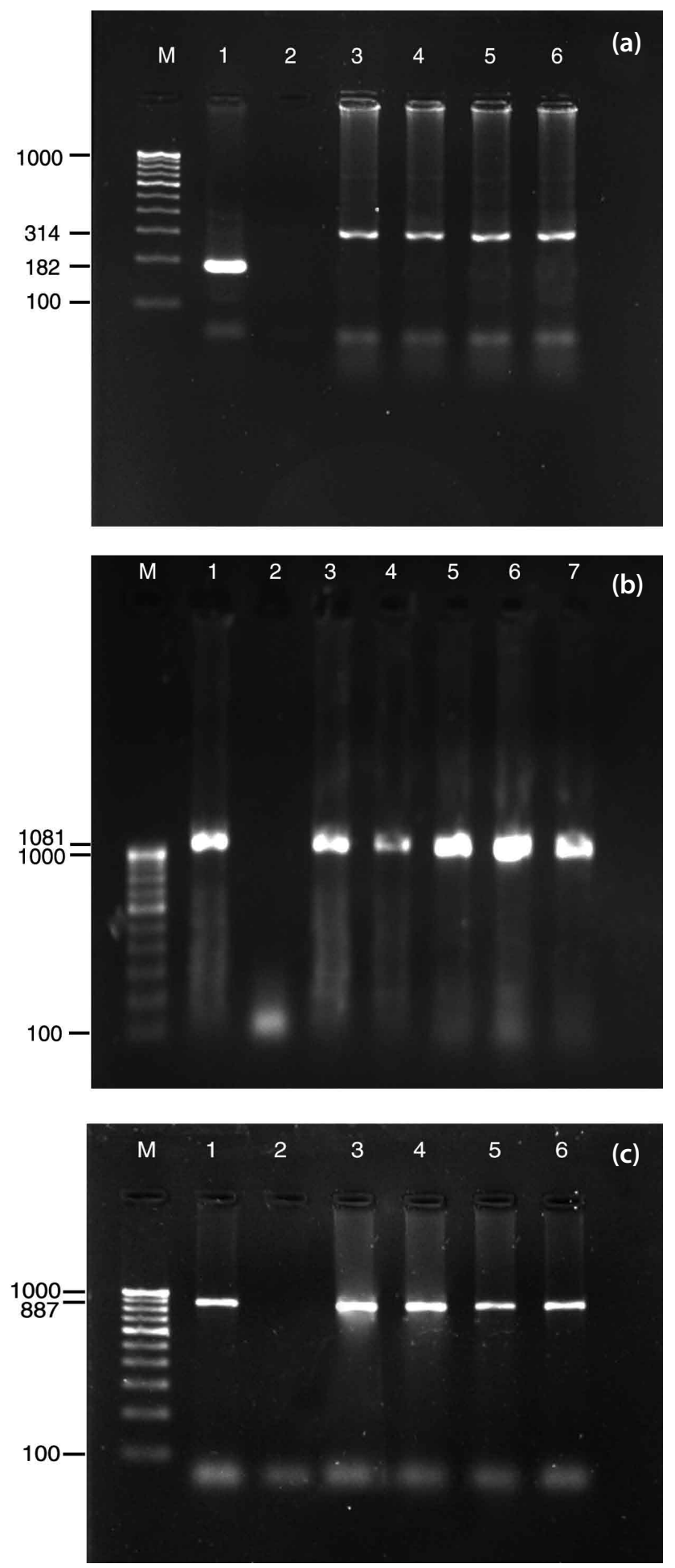

Fig. 3

PCR amplification of 132 bp repeat region, Meq and vIL-8 genes in MD affected flocks

(a) Screening of MD-suspected field samples using PCR for 132 bp repeat region; (b) PCR amplification of Meq gene of different MD-positive field samples; (c) PCR amplification of vIL-8 gene of different MD-positive field samples. 
Table 4. Sequences of vIL-8 genes MDV reference strains published in GenBank

\begin{tabular}{|c|c|c|c|c|}
\hline S. No. & MDV strains & Virulence & $\begin{array}{l}\text { Geographic } \\
\text { origin }\end{array}$ & Acc. No. \\
\hline 1 & $\mathrm{CU}-2$ & Mild & USA & EU499381 \\
\hline 2 & CVI988 & $\begin{array}{l}\text { Commercial vac- } \\
\text { cine }\end{array}$ & Netherland & DQ534538 \\
\hline 3 & LS & Virulent & China & HQ638183 \\
\hline 4 & LMS & Virulent & China & HQ658622 \\
\hline 5 & 571 & Virulent & USA & DQ534531 \\
\hline 6 & Ind/TN11/01 & Virulent & Tamil Nadu & КР644421 \\
\hline 7 & Ind/TN12/03 & Virulent & Tamil Nadu & KP644420 \\
\hline 8 & Ind/KA12/02 & Virulent & Tamil Nadu & KP644422 \\
\hline 9 & GA & Virulent & USA & AF147806 \\
\hline 10 & Md5 & Very virulent & USA & AF489275 \\
\hline 11 & $\mathrm{RB} 1 \mathrm{~B}$ & Very virulent & USA & EF523390 \\
\hline 12 & 595 & Very virulent & USA & DQ534533 \\
\hline 13 & $648 \mathrm{~A}$ & Very virulent plus & USA & DQ534534 \\
\hline 14 & $584 \mathrm{~A}$ & Very virulent plus & USA & DQ534532 \\
\hline
\end{tabular}

The representative nucleotide sequences (26) of Meq gene of different pathotypes such as mild (m), virulent $(\mathrm{v})$, very virulent $(\mathrm{vv})$ and very virulent plus $(\mathrm{vv}+)$ MDVs were selected from GenBank (Table 3), were compared with field MDV sequences using MEGA 6.0 software and the results showed 84.5 to $99.6 \%$ homology. The nucleotide sequences of AP01, AP03 and AP02, AP04 had the highest homology of 99.6 and $99.5 \%$ with strains RB1B and GA, and had the lowest homology of 84.5 and $84.4 \%$ with CVI988 strain, respectively.

Comparison of four field MDV nucleotide sequences of Meq gene with reference strains RB1B (very virulent) and GA (virulent) showed variations at four positions in sequences of AP01 and AP03 and five variations in sequences of AP02 and AP04. AP01 showed mutations at positions $229(A \rightarrow G), 238(G \rightarrow T), 415(A \rightarrow G), 626(T \rightarrow C)$; whereas AP03 showed mutations at $229(A \rightarrow G), 238(G \rightarrow T), 278$ $(A \rightarrow G), 415(A \rightarrow G)$ of 1020 nucleotides of the Meq gene. Nucleotide mutations at positions $229(A \rightarrow G), 238(G \rightarrow T)$,

Table 5. Amino acid substitutions in the Meq protein of MDV-1 field strains compared with reference strains

\begin{tabular}{|c|c|c|c|c|c|c|c|c|c|c|c|c|c|c|c|c|c|c|c|}
\hline \multirow[b]{2}{*}{ S. No. } & \multirow{2}{*}{$\begin{array}{l}\text { Virulence \& } \\
\text { field samples }\end{array}$} & \multirow[b]{2}{*}{ Strain name } & \multicolumn{17}{|c|}{ Amino acid substitutions in the Meq protein of MDV-1 field strains and reference strains } \\
\hline & & & 71 & 77 & 80 & 88 & 93 & 115 & 119 & 139 & 153 & 176 & 180 & $\begin{array}{l}209 / \\
268^{a}\end{array}$ & $\begin{array}{l}217 / \\
276^{\mathrm{a}}\end{array}$ & $\begin{array}{l}277 / \\
336^{\mathrm{a}}\end{array}$ & $\begin{array}{l}283 / \\
342^{\mathrm{a}}\end{array}$ & $\begin{array}{l}320 / \\
379^{\mathrm{a}}\end{array}$ & $\begin{array}{l}326 / \\
385^{\mathrm{a}}\end{array}$ \\
\hline 1 & $\mathrm{Vv}$ & Strain RB1B & A & $\mathrm{K}$ & $\mathrm{D}$ & A & Q & $\mathrm{V}$ & $\mathrm{C}$ & $\mathrm{T}$ & $\mathrm{P}$ & $\mathrm{P}$ & $\mathrm{T}$ & $\mathrm{L}$ & $\mathrm{P}$ & $\mathrm{L}$ & A & I & $\mathrm{T}$ \\
\hline 2 & $\mathrm{~V}$ & Strain GA & . & . & . & . & . & . & . & . & . & . & . & . & . & . & . & . & . \\
\hline 3 & $\mathrm{~V}$ & Strain 567 & . & $\mathrm{E}$ & $\mathrm{Y}$ & . & . & . & $\mathrm{R}$ & . & . & . & . & . & A & . & . & . & . \\
\hline 4 & $\mathrm{~V}$ & Strain 617A & . & $\mathrm{E}$ & $\mathrm{Y}$ & . & . & . & $\mathrm{R}$ & . & . & . & . & . & A & . & . & . & . \\
\hline 5,6 & $\mathrm{~V}$ & Strain 571,573 & . & $\mathrm{E}$ & $\mathrm{Y}$ & . & . & $\mathrm{A}$ & . & . & . & $\mathrm{H}$ & . & . & . & . & . & . & . \\
\hline 7 & Field sample & AP01 Meq & . & $\mathrm{E}$ & $\mathrm{Y}$ & . & . & . & . & A & . & . & . & $\mathrm{P}$ & . & . & . & . & . \\
\hline 8 & Field sample & AP02 Meq & . & $\mathrm{E}$ & $\mathrm{Y}$ & $\mathrm{T}$ & $\mathrm{R}$ & . & . & A & . & . & . & . & . & . & . & . & . \\
\hline 9 & Field sample & AP03 Meq & . & $\mathrm{E}$ & $\mathrm{Y}$ & . & $\mathrm{R}$ & . & . & A & . & . & . & . & . & . & . & . & . \\
\hline 10 & Field sample & AP04 Meq & . & $\mathrm{E}$ & $\mathrm{Y}$ & $\mathrm{T}$ & $\mathrm{R}$ & . & . & A & . & . & . & . & . & . & . & . & . \\
\hline 11 & TN Isolate & Ind/TN11/01 & . & $\mathrm{E}$ & $\mathrm{Y}$ & $\mathrm{T}$ & $\mathrm{R}$ & . & . & A & . & . & . & . & . & . & . & . & . \\
\hline 12 & TN Isolate & Ind/TN12/03 & . & $\mathrm{E}$ & $\mathrm{Y}$ & $\mathrm{T}$ & $\mathrm{R}$ & . & . & A & . & . & . & . & . & . & . & . & . \\
\hline 13 & KA Isolate & Ind/KA12/02 & . & $\mathrm{E}$ & $\mathrm{Y}$ & $\mathrm{T}$ & $\mathrm{R}$ & . & . & A & . & . & . & . & . & . & . & . & . \\
\hline 14 & $\mathrm{Vv}$ & Isolate Tn-n1 & . & . & . & . & . & . & . & . & . & . & . & $\mathrm{P}$ & . & . & . & . & . \\
\hline 15 & $\mathrm{Vv}$ & Isolate Tn-n2 & . & . & . & . & . & . & . & . & . & . & . & $\mathrm{P}$ & . & . & . & . & . \\
\hline 16 & $\mathrm{~V}$ & Strain $\mathrm{BC}-1^{\mathrm{a}}$ & S & A & . & . & . & A & . & . & . & . & . & . & . & . & . & . & . \\
\hline 17 & $\mathrm{~V}$ & Strain JM ${ }^{\mathrm{a}}$ & S & A & . & . & $\mathrm{R}$ & A & . & . & . & . & . & . & . & . & . & . & . \\
\hline 18 & M & Strain CU-2 $2^{\mathrm{a}}$ & S & $\mathrm{E}$ & . & . & . & . & . & . & . & . & . & . & . & . & . & . & . \\
\hline 19 & Vaccine & Strain CVI988 & S & $\mathrm{E}$ & . & . & . & . & . & . & . & . & . & . & . & . & . & . & I \\
\hline 20 & $\mathrm{Vv}$ & Strain Md5 & . & . & . & . & . & . & . & . & . & . & . & . & $\mathrm{A}$ & . & $\mathrm{V}$ & $\mathrm{T}$ & . \\
\hline 21 & $\mathrm{Vv}+$ & Strain W & . & . & . & . & . & . & . & . & . & . & . & . & A & . & $\mathrm{V}$ & $\mathrm{T}$ & . \\
\hline 22 & $\mathrm{Vv}$ & Strain $643 \mathrm{P}$ & . & . & . & . & . & . & $\mathrm{R}$ & . & Q & A & A & . & A & $\mathrm{F}$ & . & . & . \\
\hline 23,24 & $\mathrm{Vv}+$ & Strain New, 584A & . & . & . & . & . & . & $\mathrm{R}$ & . & Q & A & . & . & A & . & $\mathrm{V}$ & $\mathrm{T}$ & . \\
\hline 25,26 & $\mathrm{Vv}$ & Strain 549,595 & . & . & . & . & . & . & $\mathrm{R}$ & . & Q & A & A & . & A & . & . & . & . \\
\hline 27,28 & $\mathrm{Vv}+$ & Strain L,X & . & . & . & . & . & . & $\mathrm{R}$ & . & Q & A & A & . & A & . & . & . & . \\
\hline 29 & $\mathrm{Vv}+$ & Strain 648A & S & $\mathrm{E}$ & . & . & . & A & . & . & . & . & . & . & . & . & . & . & . \\
\hline 30 & $\mathrm{Vv}+$ & Strain N & . & . & . & . & . & . & $\mathrm{R}$ & . & $\mathrm{Q}$ & $\mathrm{A}$ & $\mathrm{A}$ & . & A & $\mathrm{P}$ & . & . & . \\
\hline
\end{tabular}

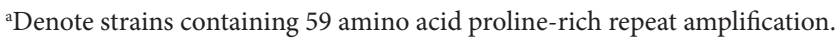


$262(G \rightarrow A), 278(A \rightarrow G), 415(A \rightarrow G)$ of Meq gene were seen in AP02 and AP04.

Comparison of nucleotide sequences of Meq gene of four field MDVs (AP01, AP02, AP03 and AP04) with sequences of other Indian field isolates (Ind/TN11/01 and Ind/KA12/02) revealed that the sequences are $100 \%$ identical with AP02 and AP04. The nucleotide sequence of AP03 showed one variation at position $262(A \rightarrow G)$ and AP01 nucleotide sequence showed variations at three positions $262(A \rightarrow G), 278(G \rightarrow A)$ and $626(\mathrm{~T} \rightarrow \mathrm{C})$.

Comparison of the nucleotide sequences of vIL- 8 gene of field samples with the sequences of 14 reference strains (Table 4) showed 99.44 to $99.87 \%$ nucleotide homology. The sequences of four field samples had the highest homology of 99.87\% with virulent strains LS and LMS and had the lowest homology of $99.44 \%$ with CVI988 strain. Comparison of four field MDV nucleotide sequences of vIL-8 gene with reference strain LMS showed one variation at position 106 $(\mathrm{T} \rightarrow \mathrm{C})$ in all the sequences. Also one nucleotide deletion in the sequence of AP02 was seen at position 815 instead of base T. Comparison of nucleotide sequences of vIL- 8 gene of four field MDVs (AP01, AP02, AP03 and AP04) with sequences of other Indian field isolates (Ind/TN11/01, Ind/TN12/03 and Ind/KA12/02) showed 100\% similarity.

Amino acid sequence analysis of oncogenes (Meq and vIL-8)

The total length of Meq protein was 339 amino acids and the total length of vIL- 8 protein was 134 amino acids. Comparison of Meq and vIL- 8 amino acid sequences of four representative field samples from different regions (Tirupati, Guntur, Chittoor, Tanuku) was done with those of reference strains and other Indian field isolates.

Alignment analysis of the deduced amino acid sequences of Meq gene of four field samples and 26 published MDVs was performed using MEGA 6.0 Software. The amino acid mutation in the Meq protein of MDVs displayed regularity at nine positions, including $71,77,80,115,119,139,153$, 176 and 217. Low virulence MDV strains including CU-2, BC-1, JM and CVI988 showed 59 amino acid insertion with proline-rich repeats in the deduced amino acid sequences of the Meq protein. In very virulent plus ( $\mathrm{vv}+$ ) MDVs, there was an amino acid mutation at position $119(\mathrm{C} \rightarrow \mathrm{R})$. Higher virulence ( $\mathrm{vv}$ and $\mathrm{vv}+$ ) MDVs had point mutations at the positions $153(\mathrm{P} \rightarrow \mathrm{Q}), 176(\mathrm{P} \rightarrow \mathrm{A})$ and $217(\mathrm{P} \rightarrow \mathrm{A})$, which were not present in the amino acid sequences of field samples. The amino acid sequences of the Meq protein of the field strains were neither mild type nor very virulent plus MDVs. There was a mutation at position $71(\mathrm{~S} \rightarrow \mathrm{A})$ in the Meq protein of the field strains, which is associated with higher virulence in the MDV strains (Table 5).

Compared to closely related strains 571 and 573 (v), AP01, AP02, AP03 and AP04 showed variations at amino
Table 6. Amino acid substitutions in the vIL-8 protein of MDV-1 field and reference strains

\begin{tabular}{|c|c|c|c|c|c|c|}
\hline \multirow[t]{2}{*}{ S. No. } & \multirow[t]{2}{*}{$\begin{array}{l}\text { Virulence and } \\
\text { field samples }\end{array}$} & \multirow[t]{2}{*}{ Strain name } & \multicolumn{4}{|c|}{$\begin{array}{l}\text { Aminoacid substitutions } \\
\text { in the vIL-8 protein } \\
\text { of MDV } 1 \text { field and } \\
\text { reference strains }\end{array}$} \\
\hline & & & 4 & 31 & 67 & 81 \\
\hline 1 & $\mathrm{~V}$ & Strain LMS & $S$ & G & $\mathrm{M}$ & $\mathrm{E}$ \\
\hline 2 & $\mathrm{~V}$ & Strain LS & . & . & I & G \\
\hline 3 & Field sample & AP01 vIL-8 & . & . & I & . \\
\hline 4 & Field sample & AP02 vIL-8 & . & . & I & . \\
\hline 5 & Field sample & AP03 vIL-8 & . & . & I & . \\
\hline 6 & Field sample & AP04 vIL-8 & . & . & I & . \\
\hline 7 & $\mathrm{Vv}$ & Ind/KA12/02 & . & . & I & . \\
\hline 8 & $\mathrm{~V}$ & Ind/TN11/01 & . & . & I & . \\
\hline 9 & $\mathrm{~V}$ & Ind/TN12/02 & . & . & I & . \\
\hline 10 & $\mathrm{~V}$ & Strain 571 & $\mathrm{~L}$ & $\mathrm{D}$ & I & . \\
\hline 11 & $\mathrm{~V}$ & Strain GA & $\mathrm{L}$ & $\mathrm{D}$ & I & . \\
\hline 12 & $\mathrm{Vv}$ & Strain RB1B & $\mathrm{L}$ & $\mathrm{D}$ & I & . \\
\hline 13 & $\mathrm{Vv}$ & Strain Md5 & $\mathrm{L}$ & $\mathrm{D}$ & I & . \\
\hline 14 & Vv & Strain 595 & $\mathrm{~L}$ & $\mathrm{D}$ & I & . \\
\hline 15 & $\mathrm{Vv}+$ & Strain $584 \mathrm{~A}$ & $\mathrm{~L}$ & $\mathrm{D}$ & I & . \\
\hline 16 & $\mathrm{Vv}+$ & Strain 648A & $\mathrm{L}$ & $\mathrm{D}$ & I & . \\
\hline 17 & $\mathrm{~m}$ & Strain CU-2 & $\mathrm{L}$ & $\mathrm{D}$ & I & . \\
\hline 18 & Vaccine & Strain CVI988 & $\mathrm{L}$ & $\mathrm{D}$ & $\mathrm{I}$ & . \\
\hline
\end{tabular}

acid positions 209; 88, 93, 115, 139; 93, 115, 139 and 88, 93, 115, 139, respectively. Minimum amino acid variations were present in all four field amino acid sequences of Meq in comparison with the deduced amino acid sequences of virulent strains 571 and 573. Hence, the field MDV strains obtained in the present study could be categorized into virulent pathotypes.

Comparison of the deduced amino acid sequences of Meq protein of four field MDVs (AP01, AP02, AP03 and AP04) with other Indian field isolates (Ind/TN11/01 and Ind/ KA12/02) showed no variations in the amino acid sequences of AP02 and AP04. There were three variations in the amino acid sequence of AP01 at positions $88(T \rightarrow A), 93(R \rightarrow Q)$ and $209(\mathrm{~L} \rightarrow \mathrm{P})$ and one variation in the amino acid sequence of AP03 at position $88(\mathrm{~T} \rightarrow \mathrm{A})$.

Amino acid sequence analysis of vIL- 8 gene of four field samples (AP01, AP02, AP03 and AP04) and 14 published MDVs was performed (Table 6). Comparison of amino acid sequences of vIL- 8 protein with that of reference strains like CU-2, GA, RB1B, 648A, 584A, Md5, 595, 571 and CVI988 showed that mutations exist at position $4(\mathrm{~L} \rightarrow \mathrm{S})$ and $31(D \rightarrow G)$. The amino acid mutations at positions 4 and 31 were similar to the virulent reference strains LMS and LS. In comparison with that of the other Indian field isolates, the field MDV strains showed no variations in these sequences. 


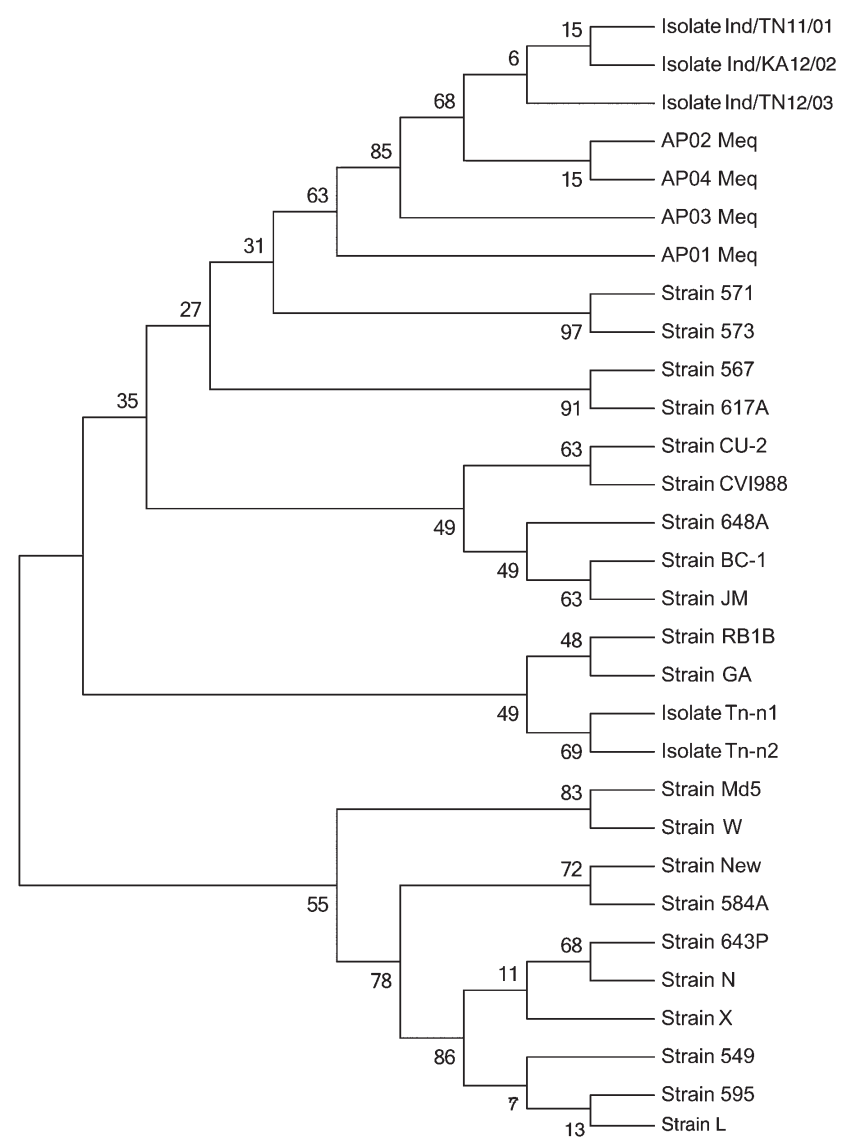

Fig. 4

Phylogenetic analysis of Meq gene nucleotide sequences of four field MDV strains with other reference sequences available in NCBI database

The phylogenetic tree was constructed using the MEGA version 6.0 by the neighbor-joining method with 1000 bootstrap replicates using Tamura nei model.

\section{Phylogenetic analysis of oncogenes}

The phylogenetic analysis of Meq gene of the field MDV nucleotide sequences with different reference strains formed a cluster with virulent MDV strains 571, 573 and other Indian MDV strains (Fig. 4).

The phylogenetic analysis of vIL8 gene of the field MDV nucleotide sequences with different reference strains showed that they formed a cluster with virulent strains LS and LMS and other Indian MDV strains (Fig. 5).

\section{Discussion}

Marek's disease is one of the most important diseases of poultry and is responsible for great economic losses to the poultry industry worldwide. In India, poultry farmers were

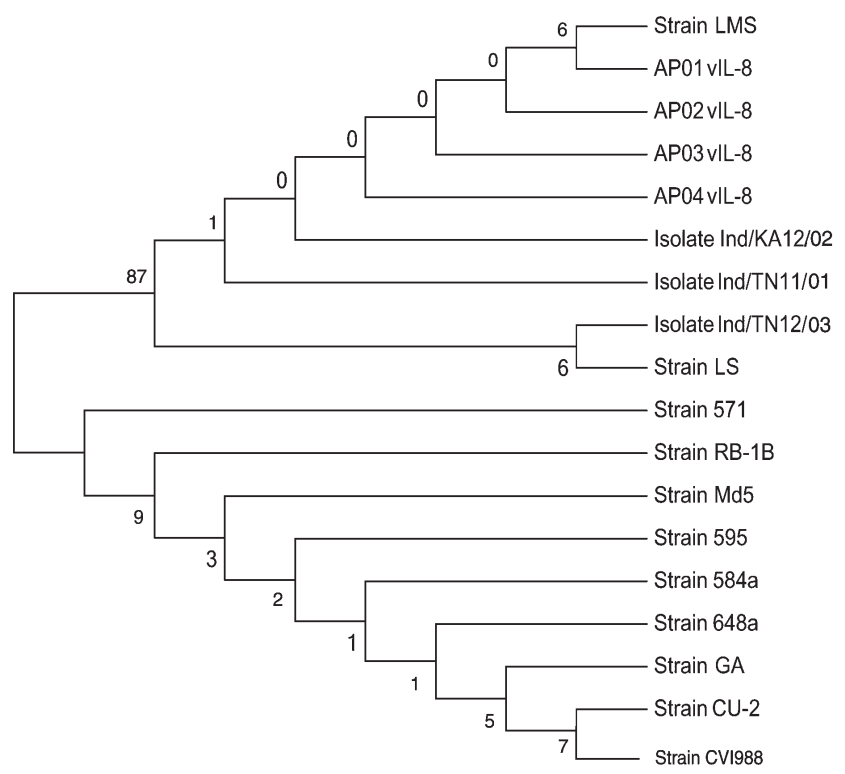

Fig. 5

Phylogenetic analysis of vIL-8 gene nucleotide sequences of four field MDV strains with other reference sequences available in NCBI database

The phylogenetic tree was constructed using the MEGA version 6.0 by the neighbor-joining method with 1000 bootstrap replicates using Tamura nei model.

practicing HVT vaccination for the control of MDV and more recently bivalent vaccines are being used. Sporadic outbreaks of MD have been reported recently even after vaccination with bivalent vaccines. In Indian poultry flocks, in the past few years, there appears to be a significant change in the clinical manifestation of MD from classical/paralytic form to an acute lymphomatosis resulting in tumor formation in affected birds. The probable reasons could be the increased virulence of MDV, which led to the emergence of more virulent serotype-1 MDV strains. The genome of serotype-1 MDVs contains several oncogenes, which are important in viral pathogenesis and oncogenesis (Tulman et al., 2000). Of these, Meq (Jones et al., 1992), vIL-8 (Parcells et al., 2001) and pp38 (Cui et al., 1991) genes are most important in viral oncogenesis of serotype-1 MDVs (Wozniakowski et al., 2010; Tian et al., 2011). Mutations in nucleotide sequences of Meq and vIL-8 genes are most important in evolution of serotype-1 MDV s from less virulent to most virulent forms that result in high mortality rates with infiltration of lymphoblastoid cells in different visceral organs (Silva, 1992; Shamblin et al., 2004; Tian et al., 2011; Kumar et al., 2012; Gong et al., 2013).

In the present study, characterization of viral oncogenes of MDV from the poultry flocks was carried out. For this, primers were synthesized to specifically amplify $132 \mathrm{bp}$ repeat region in MDV genome. Amplification of 132 bp re- 
peat region can distinguish pathogenic and non-pathogenic MDVs (Becker et al., 1992; Silva, 1992). The clinical samples from the MD outbreaks yielded a 314 bp product in PCR, which indicates the presence of two copies of $132 \mathrm{bp}$ tandem repeats. All pathogenic serotype-1 MDVs contain two or three copies of $132 \mathrm{bp}$ tandem repeats in their genome (Becker et al., 1992; Silva et al., 2004; Doosti and Golshan, 2011). The samples, which were detected as positive for 132 bp repeat region, were used for amplification of oncogenes. Sequence analysis of Meq and vIL-8 genes of MDV was done. Maximum sequence homology of Meq gene showed 99.6 and $99.5 \%$ was with RB-1B (very virulent) and GA (virulent) strains. The sequences of vIL- 8 gene of field strains had the highest homology of $99.87 \%$ with virulent strains LS and LMS.

The present study showed that Meq is the most important oncogene, which shows variable mutations in MDVs of different virulence. The Meq gene is present only among oncogenic MDV strains. The vaccine strains, i.e. HVT and MDV serotype-2, lack Meq gene, it is therefore likely that the changes in Meq gene might have occurred as a result of functional selection for their effects on MDV and/or cellular gene expression. The phylogenetic analysis of the nucleotide sequences of Meq and vIL- 8 genes revealed that the field samples grouped with virulent MDV strains.

In conclusion, the present study demonstrates that based on the nucleotide, amino acid and phylogenetic analysis of oncogenes, the MDV strains obtained in the outbreaks of Andhra Pradesh, India could be designated as virulent MDVs. However, in India we are still practicing HVT or bivalent vaccines, and serotype-1 MD viruses are not yet used for vaccination in the field conditions. In the context of emergence of more virulent MD viruses in the southern parts of India and failure of present MD vaccines, it is appropriate to recommend usage of more efficient serotype-1 MDV vaccine strains in the poultry flocks in order to control $\mathrm{MD}$ in the country.

Acknowledgment. We thank Sri Venkateswara Veterinary University, Tirupati, Andhra Pradesh for providing monetary support in the form of stipend to prosecute my post graduation study.

\section{References}

Becker Y, Asher Y, Tabor E, Davidson I, Malkinson M, Weisman Y (1992): Polymerase chain reaction for differentiation between pathogenic and non-pathogenic serotype 1 Marek's disease virus (MDV) and vaccine viruses of MDV-serotypes 2 and 3. J. Virol. Methods 40, 307-322. https://doi.org/10.1016/0166-0934(92)90089-V

Biggs PM, Nair V (2012): The long view: 40 years of Marek's Disease Research and Avian Pathology. Avian Pathol. 41, 3-9. https://doi.org/10.1080/03079457.2011.646238
Brown AC, Baigent SJ, Smith LP, Chattoo JP, Petherbridge LJ, Hawes P, Allday MJ, Nair V (2006): Interaction of MEQ protein and C-terminal- binding protein is critical for induction of lymphomas by Marek's disease virus. Proc. Natl. Acad. Sci. USA 103, 1687-1692. https://doi.org/10.1073/ pnas.0507595103

Bulow VV, Biggs PM (1975): Differentiation between strains of Marek's disease virus and turkey herpes virus by immunofluorescence assays. Avian Pathol. 4, 133-146. https:// doi.org/10.1080/03079457509353859

Cui ZZ, Lee LF, Liu JL, Kung HJ (1991): Structural analysis and transcriptional mapping of the Marek's disease virus gene encoding pp38, an antigen associated with transformed cells. J. Virol. 65, 6509-6515.

Culling CFA (1974): Hand Book of Histopathological and Histochemical Techniques Including Museum Techniques. 3rd Ed., pp. 361.

Doosti A, Golshan M (2011): Molecular study for detection of Marek's disease virus (MDV) in southwest of Iran. Sci. Res. Essays. 6, 2560-2563.

Gong Z, Zhang L, Wang J, Chen L, Shan H, Wang Z, Ma H (2013): Isolation and analysis of a very virulent Marek's disease virus strain in China. Virol. J. 10,115. https://doi. org/10.1186/1743-422X-10-155

Jones D, Lee L, Liu JL, Kung HJ, Tillotson JK (1992): Marek's disease virus encodes a basic-leucine zipper gene resembling the fos/ jun oncogenes that is highly expressed in lymphoblastoid tumors. Proc. Natl. Acad. Sci. USA 89, 4042-4046. https://doi.org/10.1073/pnas.89.9.4042

Kumar P, Dong H, Lenihan D, Gaddamanugu S, Katneni U, Shaikh S, Hotz PT, Reddy SM, Peters W, Parcells MS (2012): Selection of a Recombinant Marek's Disease Virus In Vivo Through Expression of the Marek's EcoRI-Q (Meq)-Encoded Oncoprotein: Characterization of an rMd5-Based Mutant Expressing the Meq of Strain RB-1B. Avian Dis. 56, 328-340. https://doi.org/10.1637/9955-100611-Reg.1

Parcells MS, Lin SF, Dienglewicz RL, Majerciak V, Robinson DR, Chen HC, Wu Z, Dubyak GR, Brunovskis P, Hunt HD (2001): Marek's disease virus (MDV) encodes an interleukin-8 homolog (vIL-8): characterization of the vIL-8 protein and a vIL-8 deletion mutant MDV. J. Virol. 75, 5159-5173. https://doi.org/10.1128/JVI.75.11.5159$\underline{5173.2001}$

Sambrook J, Russell DW (2001): Molecular Cloning: A Laboratory Manual. 3rd Edition Cold Spring Harbor Laboratory Press, Cold Spring Harbor, New York, pp. 57-110.

Shamblin CE, Greene N, Arumugaswami V, Dienglewicz RL, Parcells MS (2004): Comparative analysis of Marek's disease virus (MDV) glycoprotein-, lytic antigen pp38and transformation antigen Meq-encoding genes: association of Meq mutations with MDVs of high virulence. Vet. Microbiol. 102, 147-167. https://doi.org/10.1016/j. vetmic.2004.06.007

Silva RF (1992): Differentiation of pathogenic and non-pathogenic serotype 1 Marek's disease viruses (MDVs) by the polymerase chain reaction amplification of the tandem direct repeats within the MDV genome. Avian Dis. 36, 521-528. https://doi.org/10.2307/1591744 
Silva RF, Reddy SM, Lupiani B (2004): Expansion of a unique region in the Marek's disease virus genome occurs concomitantly with attenuation but is not sufficient to cause attenuation. J. Virol. 78, 733-740. https://doi.org/10.1128/ JVI.78.2.733-740.2004

Tian M, Zhao Y, Lin Y, Zou N, Liu C, Liu P, Cao S, Wen X, Huang Y (2011): Comparative analysis of oncogenic genes revealed unique evolutionary features of field Marek's disease virus prevalent in recent years in China. J. Virol. 8, 121-131. https://doi.org/10.1186/1743-422X-8-121

Tulman ER, Afonso CL, Lu Z, Zsak L, Rock DL, Kutish GF (2000): The genome of a very virulent Marek's disease virus. J. Virol. 74, 7980-7988. https://doi.org/10.1128/ IVI.74.17.7980-7988.2000

Witter RL (1997): Increased virulence of Marek's disease virus field isolates. Avian Dis. 41,149-63. https://doi. org/10.2307/1592455

Witter RL, Calnek BW, Buscaglia G, Gimeno IM, Schat KA (2005): Classification of Marek's disease viruses according to pathotype: Phylosophy and Methodology. Avian Pathol. 34, 75-90. https://doi.org/10.1080/03079450500059255

Woźniakowski G, Samorek ES, Kozdruń W (2010): Sequence analysis of meq oncogene among polish strains of Marek's disease. Pol. J. Vet. Sci. 13, 263-267. 